\title{
SOSIALISASI PROGRAM PENCEGAHAN COMPUTER VISION SYNDROME (CVS) PADA MAHASISWA STIKES SUAKA INSAN BANJARMASIN
}

\author{
Utomo Wicaksono $^{*}$, Wendelinus Imus ${ }^{2}$ \\ ${ }^{1,2}$ Sarjana Fisioterapi, Sekolah Tinggi Ilmu Kesehatan Suaka Insan Banjarmasin \\ *Email : tomwicaksono@gmail.com
}

\begin{abstract}
ABSTRAK
Penggunaan teknologi seperti komputer dan gawai oleh mahasiswa STIKes Suaka Insan dalam proses pembelajaran tanpa rekayasa manajamen yang tepat dapat menyebabkan terjadinya Computer Vision Syndrome (CVS). CVS merupakan keluhan kesehatan yang dapat menyebabkan gangguan performa maupun produktivitas dalam proses pembelajaran. Kegiatan sosialisasi terkait CVS perlu dilakukan dalam upaya pencegahan terjadinya CVS dan progresifitas CVS kearah yang lebih buruk. Sosialisasi diberikan dengan metode ceramah dan diskusi. Sebelum dan setelah kegiatan sosialisasi responden diberikan angket untuk mengukur tingkat pengetahuan responden. Tingkat pengetahuan responden sebelum kegiatan sosialisasi mendominasi sebesar $90 \%$ berada pada kategori tidak tahu. Setelah kegiatan sosialisasi tingkat pengetahuan responden mendominasi menjadi $49 \%$ berada pada kategori tahu dan sisanya memiliki tingkat pengetahuan kategori sedikit tahu serta kategori sangat tahu. Kegiatan sosialisasi berjalan dengan baik dan berhasil.
\end{abstract}

Kata Kunci : Computer Vision Syndrome, Pencegahan, Sosialisasi

\section{A. PENDAHULUHUAN}

Sekolah Tinggi Ilmu Kesehatan (STIKes) Suaka Insan merupakan salah satu perguruan tinggi swasta yang berdiri sejak tahun 1972 mencetak tenaga kesehatan yang profesional, kompeten, dan berkarakter dengan konsep pendidikan yang tertuang dalam conceptual framework pendidikan dengan mendidik secara komprehensif dan holistik yang mengembangkan tiga pilar kehidupan manusia yaitu kepribadian, pengetahuan, dan keterampilan secara seimbang. Proses pembelajaran yang dilakukan oleh mahasiswa di STIKes Suaka Insan tidak luput dari penggunaan komputer dan gawai baik di lingkungan kampus maupun di luar lingkungan kampus.

Penggunaan komputer dan gawai membantu meningkatkan produktivitas dan efisiensi proses pembelajaran. Namun, dalam jangka waktu lama dan terus-menerus, hal ini dapat menimbulkan masalah kesehatan seperti CVS (computer vision syndrome). CVS merupakan penyebab masalah kesehatan yang paling banyak dialami oleh pengguna komputer (Anggrainy et al., 2018; Rahman \& Sanip, 2011). CVS atau juga disebut digital eye strain didefinisikan sebagai kumpulan gejala pada mata akibat aktivitas penglihatan jarak dekat terus-menerus selama 
penggunaan komputer dan gawai (Altalhi et al., 2020; Pulla et al., 2019).

Secara global, terdapat sekitar 60 juta orang yang mengalami CVS dan bertambah satu juta kasus baru setiap tahunnya (Zeleke et al., 2018). Menurut AOA (American Optometric Association), rata-rata pekerja di Amerika menggunakan komputer selama tujuh jam dalam sehari, baik di tempat kerja maupun di rumah. Dari 70 juta pekerja tersebut, $90 \%$ di antaranya mengalami CVS (Randolph, 2017). Di Asia, prevalensi CVS termasuk tinggi. Penelitian di Sri Lanka menunjukkan prevalensi CVS pada pengguna komputer sebesar 67,4\%, di Hongkong sebesar 67\%, dan di Malaysia sebesar 68,1\%. Di Indonesia, menunjukkan 97\% responden pengguna komputer mengalami CVS (Alberta et al., 2021).

CVS dapat mengakibatkan interupsi saat melakukan proses belajar sehingga berujung pada performa dan produktivitas yang menurun, kemampuan visual terganggu, gangguan muskuloskeletal, dan masalah kesehatan lain yang berkepanjangan. CVS pada negara berkembang masih tinggi, penyebabnya antara lain diduga kurangnya kesadaran dan pengetahuan terkait dengan CVS. Dari hasil observasi terhadap kebiasaan yang dilakukan mahasiswa STIKes Suaka Insan, mahasiswa saat menggunakan laptop berusaha untuk bertahan dalam waktu lama ditambah lagi melakukan postur janggal yang merupakan faktor terhadap timbulnya CVS (Alberta et al., 2021).

Dari data di atas maka diperlukan tindakan pengabdian kepada masyarakat untuk dapat mengubah pola kebiasaan mahasiswa STIKes Suaka Insan untuk dapat belajar dengan sehat dan nyaman, sehingga memiliki performa belajar yang tinggi berupa program sosialisasi atau penyuluhan dalam upaya pencegahan terhadap keluhan yang lebih buruk.

\section{B. METODE}

Tahapan penyelesaian masalah melalui kegiatan pengabdian kepada kelompok masyarakat dilakukan dengan cara observasi terkait pola kebiasaan mahasiswa STIKes Suaka Insan dalam melakukan proses belajar menggunakan komputer dan gawai. Tahap pelaksanaan dengan sosialisasi atau penyuluhan dengan metode ceramah dan tanya jawab. Kedua metode tersebut digunakan dalam upaya penyampaian informasi guna meningkatkan pengetahuan. Paparan informasi yang disampaikan dalam upaya peningkatan pengetahuan yaitu: latar belakang CVS, definisi CVS, gejala CVS, faktor-faktor CVS, program-program untuk 
pencegahan. Tahap evaluasi dengan penyebaran angket sebelum dan setelah sosialisasi untuk mengukur tingkat pengetahuan responden. Setiap item pertanyaan terdapat empat skala likert yang dapat menggambarkan kategori tingkat pengetahuan responden, yaitu 1 (tidak tahu), 2 (sedikit tahu), 3 (tahu), dan 4 (sangat tahu).

\section{HASIL DAN PEMBAHASAN}

Sebelum kegiatan sosialisasi tentang program untuk pencegahan CVS kelompok sasaran pengabdian terlebih dahulu mengisi angket yang terdiri dari enam item pertanyaan hasilnya dapat dilihat pada Grafik 1, sebagai berikut:

Grafik 1. Distribusi kategori tingkat pengetahuan responden sebelum sosialisasi

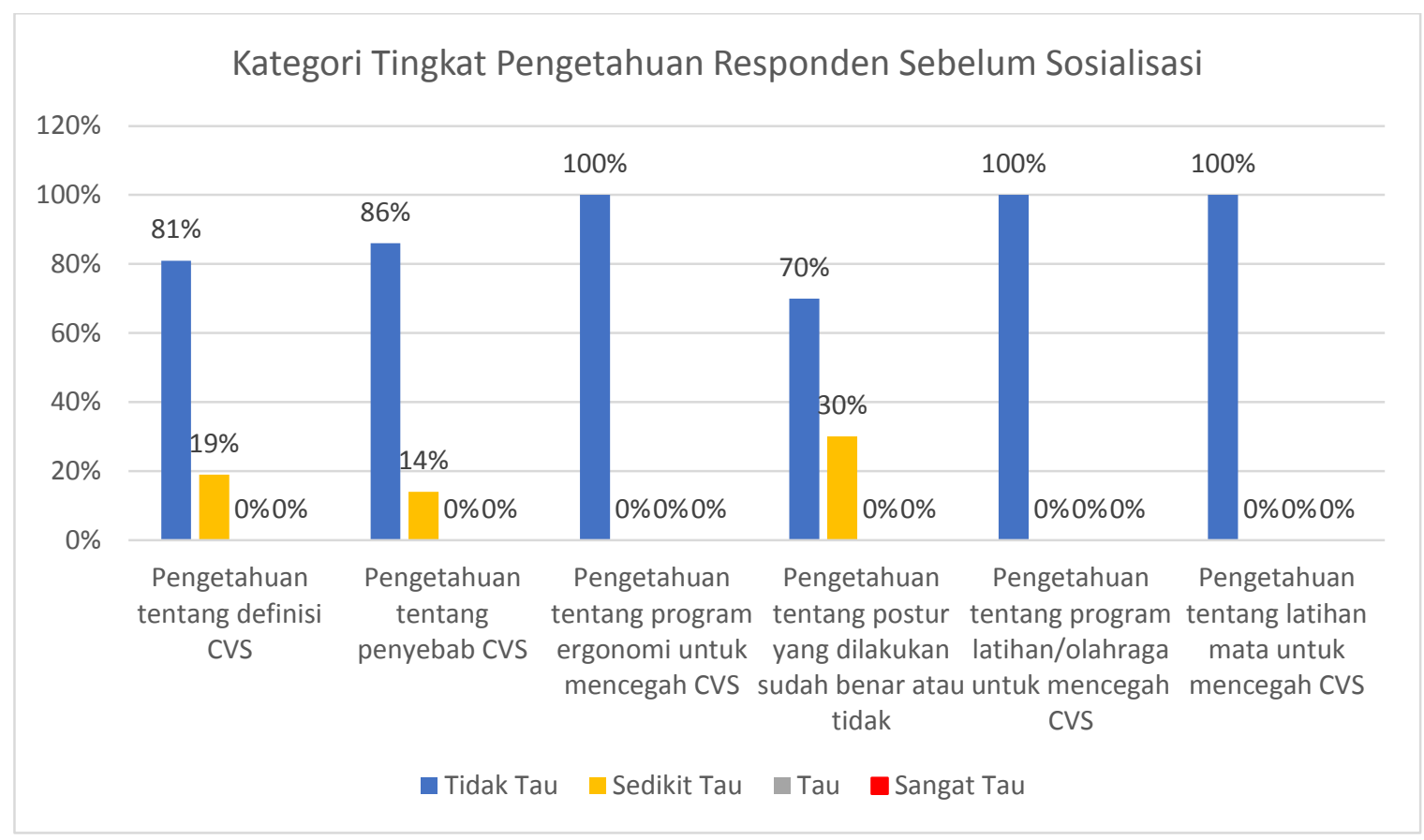

Dari pola grafik di atas dapat dinyatakan bahwa tingkat pengetahuan kelompok sasaran pengabdian sebelum sosialisasi mendominasi pada kategori tidak tahu, yaitu sebesar $90 \%$ dan sisanya memiliki kategori hanya sebatas sedikit tahu sebesar $10 \%$.
Setelah kegiatan sosialisasi tentang program untuk pencegahan CVS kelompok sasaran pengabdian mengisi angket yang terdiri dari enam item pertanyaan hasilnya dapat dilihat pada Grafik 2, sebagai berikut: 
Diagram 2. Distribusi kategori tingkat pengetahuan responden setelah sosialisasi

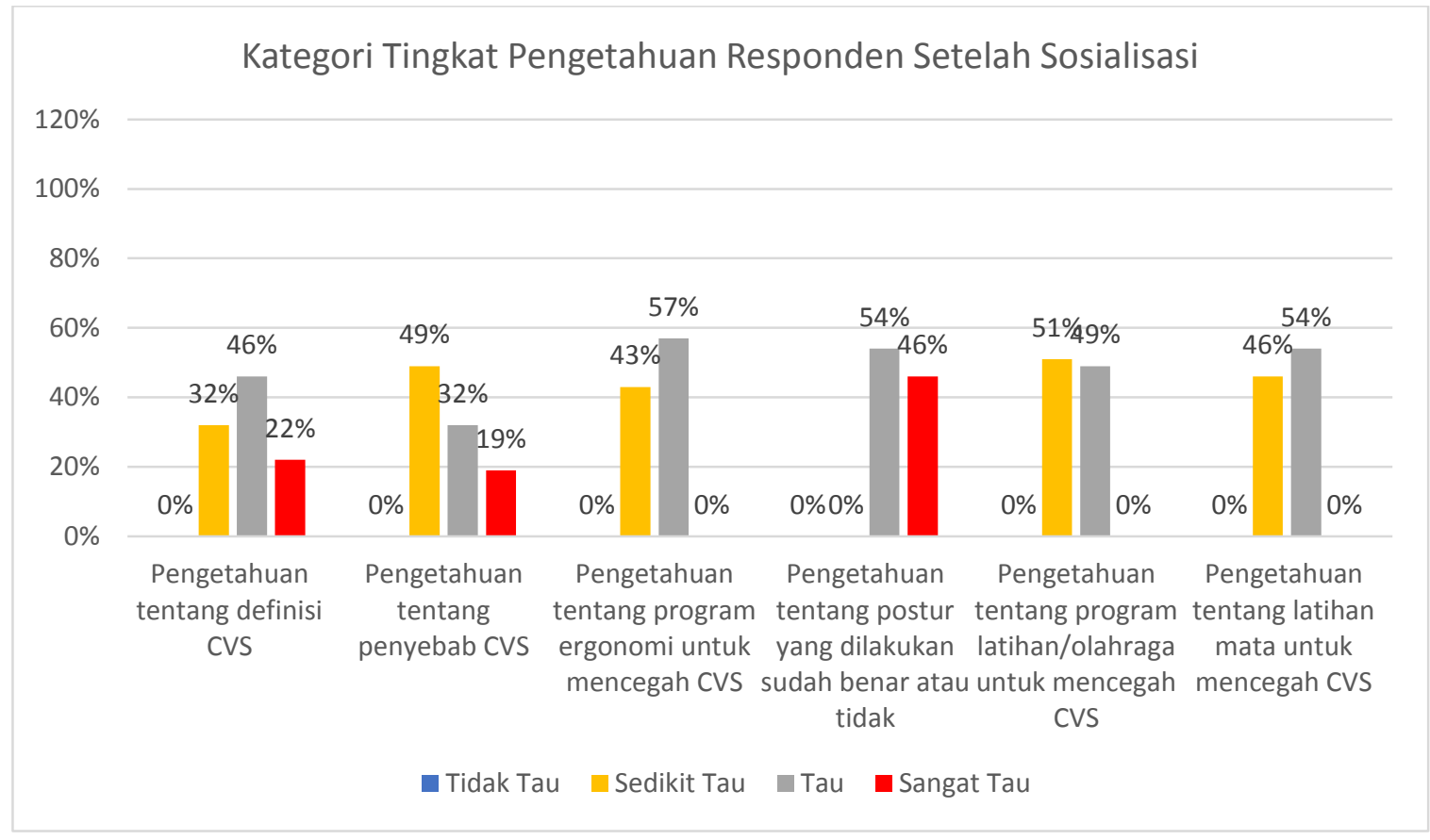

Setelah sosialisasi terjadi perubahan pola grafik, yaitu tingkat pengetahuan kelompok sasaran pengabdian mendominasi pada kategori tahu sebesar 49\%, sisanya memiliki tingkat pengetahuan pada kategori sedikit tahu $37 \%$ dan kategori sangat tahu $14 \%$. Materi sosialisasi menitikberatkan bahwa CVS dapat dicegah dengan kesadaran untuk melakukan pengendalian terhadap faktor risiko saat menggunakan komputer dan gawai dengan rekayasa manajemen berupa penerapan kaidah ergonomi, melakukan olahraga fisik, dan latihan mata (Agusdianti et al., 2017; Alberta et al., 2021; Maisal et al., 2020).

Penerapan kaidah ergonomi meliputi:
1. Terapkan rule 20-20-20, yaitu setiap menggunakan komputer atau gawai 20 menit lakukan istirahat 20 detik serta melihat objek sejauh 20 kaki (6 meter). Referensi lain menyebutkan intirahat setiap 2 jam menggunakan komputer selama 15 menit.

2. Mengedipkan mata secara teratur, idealnya 10-15 kali/menit.

3. Mengatur intensitas cahaya layar komputer sesuai dengan kenyamanan penggunanya. Jika memungkinkan gunakan anti-glare atau filter pada layar.

4. Idealnya kondisi lingkungan memiliki kelembaban 45-65\%, suhu $23-26^{\circ} \mathrm{C}$, dan pencahayaan berkaitan gambar 300 lx, berkaitan tulisan 500 
1x, selama memungkinkan gunakan cahaya alami.

5. Atur posisi tempat kerja agar tidak menyebabkan silau dengan menghindari peletakan layar berhadapan dengan jendela atau gunakan gorden, mengurangi silau dari tempat yang bersebelahan dengan menggunakan penutup lampu.

6. Terapkan postur ergonomis saat menggunakan komputer dan gawai, sebagai berikut:

a. Kepala dan leher tegak sejajar tubuh.

b. Mata dapat melirik ke bawah tanpa menekuk leher.

c. Punggung bersandar dengan nyaman pada sandaran kursi.

d. Bahu dalam kondisi relaks, siku ditekuk pada sudut $90^{\circ}$ dekat dengan tubuh, kondisi lengan bawah tersangga horizintal.

e. Pergelangan tangan tidak tertekuk.

f. Posisi paha horizontal dengan sudut pinggul $90^{\circ}$.

g. Posisi lutut membentuk sudut $90^{\circ}$.

h. Telapak kaki menapak di lantai datar atau bersandar pada sandaran kaki meja.

Panduan olahraga fisik dan latihan mata meliputi:

1. Meregangkan otot upper trapezius (sisi kanan):

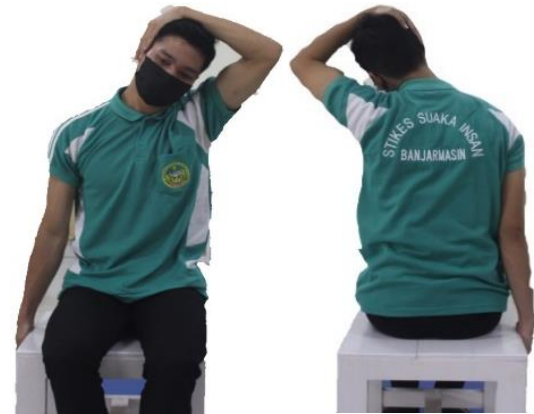

a. Pegang sisi kursi menggunakan tangan kanan.

b. Miringkan kepala anda ke sisi kiri.

c. Tambahkan tekanan regangan secara perlahan dengan bantuan tangan kiri secara perlahan.

d. Tahan posisi tersebut selama 30 detik, ulangi gerakan tersebut sebanyak 2 kali setelah itu lakukan pada sisi lainnya.

e. Latihan dilakukan secara rutin 2-3 kali perminggu.

2. Meregangkan otot levator scapulae (sisi kanan):

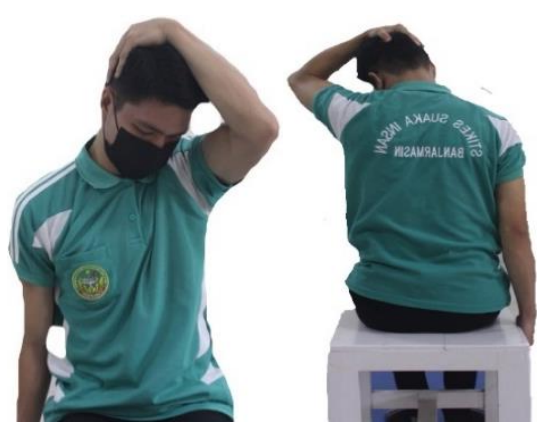

a. Pegang sisi kursi menggunakan tangan kanan.

b. Tundukan kepala anda ke arah lutut kanan. 
c. Tambahkan tekanan regangan secara perlahan dengan bantuan tangan kiri secara perlahan.

d. Tahan posisi tersebut selama 30 detik, ulangi gerakan tersebut sebanyak 2 kali setelah itu lakukan pada sisi lainnya.

e. Latihan dilakukan secara rutin 2-3 kali perminggu.

3. Meregangkan otot bahu:

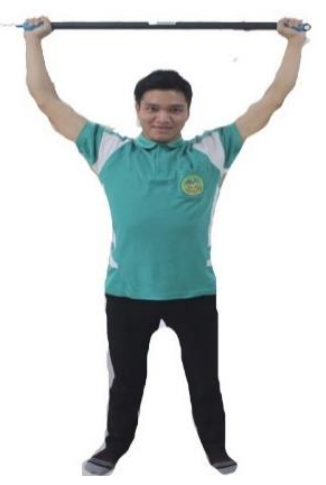

a. Pegang tongkat menggunakan kedua tangan anda.

b. Angkat tongkat ke atas hingga melewati kepala anda.

c. Tahan posisi tersebut selama 30 detik, ulangi gerakan tersebut sebanyak 2 kali setelah itu lakukan pada sisi lainnya.

d. Latihan dilakukan secara rutin 2-3 kali perminggu.

4. Penguatan otot postur:

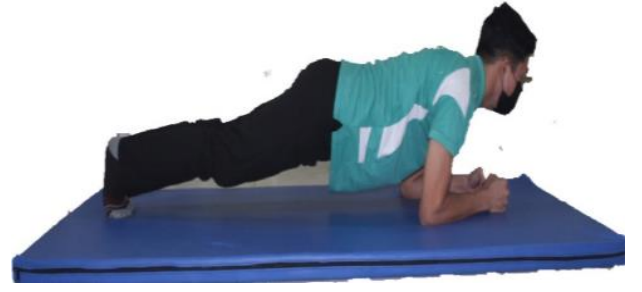

a. Posisikan tubuh anda seperti pada gambar di atas.

b. Pastikan posisi pinggang dan kepala anda lurus.

c. Tahan posisi tersebut selama 30-60 detik.

d. Latihan dilakukan secara rutin 2-3 kali perminggu.

5. Latihan Mata

Rekomendasi latihan mata dapat dilakukan setelah 2 jam atau 4 jam terus-menerus menggunakan komputer atau gawai. Gerakan dilakukan sebanyak 5 kali.

a. Gerakan 1, kepala tegak lurus ke depan kemudian lirikan mata ke atas dan ke bawah tanpa menggerakkan kepala.

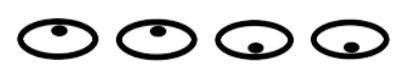

b. Gerakan 2, kepala tegak lurus ke depan kemudian lirikan mata ke kanan dan ke kiri tanpa menggerakkan kepala.

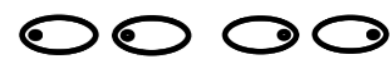

c. Gerakan 3, kepala tegak lurus ke depan kemudian lirikan mata ke kanan atas dan ke kiri atas tanpa menggerakkan kepala. 


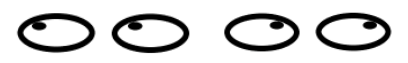

d. Gerakan 4, kepala tegak lurus ke depan kemudian lirikan mata ke kanan bawah dan ke kiri bawah tanpa menggerakkan kepala.

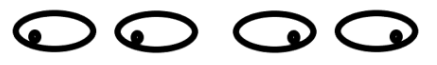

e. Gerakan 5, kepala tegak lurus ke depan kemudian lirikan mata ke kanan atas dan ke kiri bawah tanpa menggerakkan kepala.

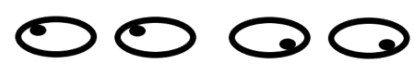

f. Gerakan 6, kepala tegak lurus ke depan kemudian lirikan mata ke kanan bawah dan ke kiri atas tanpa menggerakkan kepala.

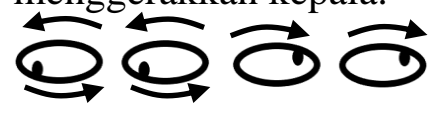

g. Gerakan 7, kepala tegak lurus ke depan kemudian putar bola mata searah jarum jam 5 kali kemudian putar bola mata berlawanan

\section{DAFTAR PUSTAKA}

Agusdianti, L. N., Sudirman, P. L., \& Muliarta, I. M. (2017). Edukasi ergonomi menurunkan keluhan muskuloskeletal dan memperbaiki konsistensi postur tubuh pada mahasiswa PSPDG Universitas Udayana. Bali Dental Journal, 1(2), 57-53.

Alberta, I. B., Sebastian, D., \& Laksono, N. V. (2021). Pendekatan multidimensional computer vision syndrome di era wfh. Cermin Dunia Kedokteran, 48(6), 350-354.

Altalhi, A., Khayyat, W., Khojah, O., dengan jarum jam 5 kali tanpa menggerakkan kepala.

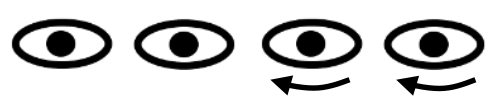

\section{KESIMPULAN}

Tingkat pengetahuan kelompok sasaran pengabdian sebelum sosialisasi mendominasi pada kategori tidak tahu dan setelah sosialisasi tingkat pengetahuan kelompok sasaran mengalami peningkatan yaitu mendominasi menjadi ada kategori tahu dan beberapa dari kelompok sasaran pengabdian juga memiliki tingkat pengetahuan kategori sangat tahu. Dengan demikian kegiatan sosialisasi dapat dinyatakan telah berjalan dengan baik dan berhasil.

Alsalmi, M., \& Almarzouki, H. (2020). Computer vision syndrome among health sciences students in Saudi Arabia: prevalence and risk factors. Cureus, 12(2), 7060-7065.

Anggrainy, P., Ashar, T., \& Lubis, R. (2018). Difference in computer vision syndrome between laptop and desktop computer users. Indonesian $J$ Medicine, 3(2), 65-70.

Maisal, F. M., Ruliati, L. P., Berek, N. C., Roga, A. U., \& Ratu, J. M. (2020). Efektivitas senam mata untuk mengurangi tingkat kelelahan mata pada pekerja rambut palsu. Jurnal 
Ergonomi Indonesia, 6(1), 9-18.

Pulla, A., Samyuktha, N., Kasubagula, S., Kataih, A., Banoth, D., \& Addagatla, H. (2019). A cross sectional study to assess the prevalence and associated factors of computer vision syndrome among engineering students of Hyderabad, Telangana. Int $J$ Community Med Public Health, 6(1), 308-313.

Rahman, Z. A., \& Sanip, S. (2011). Computer user: demographic and computer related factors that predispose user to get computer vision syndrome. Int J Bus Humanit Technol, 1(2), 84-91.

Randolph, S. (2017). Computer vision syndrome. Workplace Health and Safety, 65(7), 328-328.

Zeleke, A., Adane, F., Ahmed, A., Wami, S., \& Chercos, D. (2018). Computer vision syndrome and associated factors among computer users in Debre Tabor Town, Northwest Ethiopia. J Environmental and Public Health, 1-8. 